\title{
Kajian komparatif perancangan dan produksi peralatan saji (Studi kasus CV Estetika Indonesia)
}

\author{
Hafshoh Musfiroh ${ }^{*}$
}

Program Studi Desain Produk, Institut Seni Indonesia Yogyakarta, Indonesia

\begin{abstract}
The purpose of this study was to find out: (1) Comparison of the process of designing and producing serving serveware from wood and clay materials in CV Estetika Indonesia. (2) Types of food serveware products at CV Aesthetic Indonesia. (3) Comparison of design aspects of food and wood products from clay in CV Estetika Indonesia. This research was carried out at CV Estetika Indonesia and wood suppliers in Putat Wetan Village and Clay suppliers in Melikan Village, Klaten from 10 May to 10 June 2019. This study used a descriptive comparative method with a qualitative approach. The data used in this study are qualitative data with data sources in the form of informants, documents, observations, interviews, and documentation. Based on the results of the study it can be concluded: (1) The process of designing design serveware at $C V$ Estetika Indonesia refers to the briefs given by the buyer. The process of designing food serveware products with wood material is carried out with machines so that it is more in line with the concept of the mass product or industrial products. While clay products are more directed at handicrafts because the products are produced manually using hands. (2) Types of fast food products CV Aesthetics of wood and clay materials include trays, cutting board, bowls, plates, glasses, and coasters. (3) Design comparisons of serving serveware products include the design process, style and theme, finishing, color, ergonomics, and packaging.
\end{abstract}

Key words: serveware, wood, pottery, finishing, food servant

\begin{abstract}
Abstrak
Tujuan penelitian ini adalah untuk mengetahui: (1) Perbandingan proses perancangan dan produksi peralatan saji dari material kayu dan tanah liat di CV Estetika Indonesia. (2) Jenis Produk peralatan saji di CV Estetika Indonesia. (3) Perbandingan aspek desain dari produk peralatan saji dari kayu dan tanah liat di CV Estetika Indonesia. Penelitian ini dilaksanakan di CV Estetika Indonesia dan suplier kayu di Desa Putat Wetan serta suplier Tanah liat di Desa Melikan, Klaten mulai tanggal 10 Mei sampai 10 Juni 2019. Penelitian ini menggunakan metode komparatif deskriptif dengan pendekatan kualitatif. Data yang digunakan dalam penelitian ini adalah data kualitatif dengan sumber data berupa informan, dokumen, observasi, wawancara dan dokumentasi. Berdasarkan hasil penelitian dapat disimpulkan: (1) Proses perancangan desain peralatan saji di CV Estetika Indonesia mengacu brief yang diberikan oleh buyer. Proses perancangan produk peralatan saji dengan material kayu dilakukan dengan mesin sehingga lebih sesuai dengan konsep mass product atau produk industry. Sedangkan produk tanah liat lebih mengarah pada handycraft karena produk diproduksi secara manual menggunakan tangan. (2) Jenis produk peralatan saji CV Estetika dari material kayu dan tanah liat meliputi nampan (tray), talenan (cutting board), mangkuk (bowl), piring (plate), gelas (glass), dan tatakan gelas (coaster). (3) Perbandingan desain dari produk peralatan saji meliputi proses perancangan, gaya dan tema, finishing, warna, ergonomi, dan packaging.
\end{abstract}

Kata kunci: serveware, kayu, gerabah, finishing, penyajian makanan

\section{Pendahuluan}

Perkembangan ekonomi di Indonesia semakin pesat dan dengan berlangsungnya pasar bebas yang tidak dapat dihindarkan dari banyaknya pesaing bisnis dari berbagai negara. Menghadapi kondisi perekonomian ini, Indonesia mengalami fluktuasi nilai ekspor-impor dari tahun ke tahun. Indonesia berperan aktif dalam perdagangan ekspor migas dan non migas ke berbagai Negara di Eropa, Asia, Jepang dan lain sebagainya. Berdasarkan data perkembangan ekspor dan impor Indonesia oleh Badan Pusat

\footnotetext{
* Corresponding author Tel : +62-896-3230-7211; e-mail: haps.graphicdesign@gmail.com
} 
Statistik No. 42/05/Th. XXII tanggal 15 Mei 2019, sektor hasil industri pengolahan Januari-April 2019 mengalami penurunan $7,89 \%$ dari nilai ekspor tahun 2018.

Namun, sektor ini masih menjadi sektor tertinggi dibandingkan dengan yang lain. Di Provinsi Daerah Istimewa Yogyakarta, komoditas dari sektor industri pengolahan tersebut banyak dihasilkan oleh perusahaan level UKM (Usaha Kecil dan Menengah). Khususnya dalam bidang industri kreatif. Material dasar yang diolah menjadi produk jadi cukup beragam. Tidak saja material yang bernilai tinggi, namun juga material dari limbah buangan. Limbah industri kayu di Yogyakarta di tangan yang kreatif menjadi material untuk diolah menjadi produk home accessories yang bernilai tinggi (Prasetya, 2015) dan limbah kerang yang digunakan sebagai bahan dasar produk hotel tea set (Jayadi \& Prasetya, 2017). Bahkan material langka seperti petrified woods-pun cukup menarik perhatian UKM untuk diolah menjadi produk yang bernilai jual tinggi (Andreani \& Prasetya, 2019).

Sekalipun demikian, bagaimanapun, material yang relatif paling sering diolah sebagai produk jadi di Yogyakarta adalah kayu dan gerabah, seperti di CV Estetika Indonesia yang akan menjadi subjek penelitian ini. Kedua komoditas ini banyak digunakan sebagai bahan dasar produksi berbagai macam produk furniture, homedécor, dan lain lain. Hal tersebut dikarenakan sumber daya alam yang memadai akan bahan baku kayu maupun keramik atau sering disebut juga gerabah. Gerabah merupakan salah satu jenis kerajinan tradisional yang telah mengakar dalam sejarah seni dan kebudayaan masyarakat Indonesia. Hal ini didukung dengan berbagai bentuk kerajinan gerabah kuno yang ditemukan sejak zaman prasejarah dan munculnya sentra-sentra kerajinan gerabah di berbagai wilayah Indonesia (Oentoro, 2019).

Bahan baku kayu dan keramik atau tanah liat ini sudah tidak asing lagi di Indonesia, kedua material ini sudah digunakan oleh masyarakat pribumi sejak jaman nenek moyang sebagai bahan baku peralatan sehari-hari. Adapun peralatan sehari-hari seperti peralatan memasak, peralatan makan dan peralatan bertani.

Salah satu unsur peninggalan daerah yang diangkat pada tulisan ini adalah bagian dari penggolongan peranti memasak yakni peranti saji yang meliputi mangkuk, piring, wadah kacang dan nampan. Dinamakan peranti saji karena fungsi dan penggunaannya sebagai media untuk menyajikan makanan atau minuman.
Peranti saji sudah memiliki eksistensi dari mulai ditemukannya pada jaman ketika manusia mulai mengenal bercocok tanam. Menurut Sartono, manusia mulai mengenal seni kerajinan termasuk pembuatan peralatan dapur sejak mengenal tradisi bercocok tanam (Suranny, 2015).

Penelitian ini fokus pada peranti saji dengan material kayu dan tanah liat. Kedua material ini banyak diaplikasikan pada produk consumer goods. Material tanah liat memiliki eksistensi lebih dibandingan material kayu untuk produk peranti saji karena material ini sejak jaman dahulu diaplikasikan pada peralatan memasak dan sebagainya. Objek amatan dalam penelitian ini adalah material tanah liat (lempung) yang berasal dari daerah Bayat, Klaten. Menurut cerita sejarah, produksi kerajinan gerabah di daerah Bayat sudah ada sejak 600 tahun lalu (Yustana, 2014). Kerajinan di desa wisata ini terkenal dengan sebutan keramik Bayat. Keramik Bayat memiliki ciri khas tersendiri dan berbeda dengan daerah lain contohnya seperti daerah desa wisata Kasongan, Yogyakarta. Tanah liat Bayat dianggap lebih halus dan memiliki kualitas yang lebih baik. Produksi kerajinan di desa wisata Bayat pun telah melampaui pasar mancanegara. Kajian komparatif antara dua produk dengan material yang berbeda akan menghasilkan simpulan yang sistematis mengenai minat konsumen yang didasarkan pada studi akan unsur-unsur atau variabel yang digunakan sebagai tolok ukur. Studi komparatif ini akan mengambil beberapa unsur sebagai tolok ukur yakni proses perancangan, bentuk (gaya dan tema), finishing, warna, ergonomi, dan packaging. Dari kedua produk dengan material yang berbeda ini akan diidentifikasi perbedaan dari aspek-aspek di atas.

\section{Bahan dan Metode}

Peralatan saji memiliki berbagai jenis dengan material dan fungsi yang berbeda-beda. Menurut Insani dkk, alat penyajian terbagi menjadi 3 (tiga) jenis berdasarkan bahan dasar pembuatannya yakni, chinaware (berbahan dasar keramik), glassware (berbahan dasar kaca) dan silverware (berbahan dasar logam) (Insani, Nikmawati, \& Mahmudatussa'adah, 2016). Sedangkan menurut Sulartiningrum, pada prinsipnya peralatan yang digunakan dalam sebuah restoran dikelompokkan menjadi empat bagian yaitu: silverware, chinaware, glassware serta table accessories (Sulartiningrum, 2001).

Peralatan saji di Indonesia sudah ada sejak jaman nenek moyang. Perkembangan bentuk dan inovasi 
pun sudah sangat berkembang dari masa ke masa. Peralatan saji digolongkan sebagai peralatan dapur dan makan. Peralatan dapur dan makan pada jaman dulu sebagian besar menggunakan material tanah liat. Alat-alat tersebut meliputi: cobek, kendi, dan gelas. Pada jaman dulu dengan variasi ukuran yang berbedabeda, cobek juga difungsikan sebagai piring. Sedangkan untuk masakan dengan kuah menggunakan mangkuk semacam baskom dengan ukuran yang berbeda-beda.

Perkembangannya dalam lingkup desain produk juga sangat luas, bahkan desain saat ini menempati posisi yang tak tergantikan dalam perusahaan yang sukses. Desain dapat memberikan ide yang fantastik dalam berbagai konsentrasi perusahaan. Pada kenyataannya semua hal bermula dari sebuah desain. Maka dari itu, desain sangatlah penting karena dalam ilmu ini sesuatu dipelajari dan direncanakan dengan banyak pertimbangan aspek desain. Begitu pula dengan desain produk, desain produk memiliki peranan penting dalam kehidupan sehari-hari. Desain produk selalu berhubungan erat dengan aktivitas keseharian manusia. Dalam keilmuan desain produk, tahap-tahap yang dilalui dalam sebuah perancangan produk sangatlah komplek. Desain berkaitan dengan bentuk, fungsi juga estetika.

Menurut (Gitosudarmo, 2000), desain atau bentuk produk adalah atribut yang sangat penting untuk meningkatkan pengaruh pengambilan keputusan konsumen dalam pembelian produk. Desain yang baik dan tepat akan menghasilkan gaya (style) dan bentuk yang menarik, kinerja yang maksimal, kemudahan dan minimalisasi biaya penggunaan produk serta kesederhanaan dan keekonomisan produksi dan distribusi.

Metode yang digunakan dalam penelitian ini adalah metode penelitian komparatif yang mengacu pada teori metode Miles dan Huberman (Sugiyono, 2017) yakni terdapat 3 (tiga) proses, yaitu reduksi data, penyajian data dan kemudian kesimpulan (penarikan kesimpulan dan verifikasi data). Gambar 1 memperlihatkan komponen-komponen analisis data.

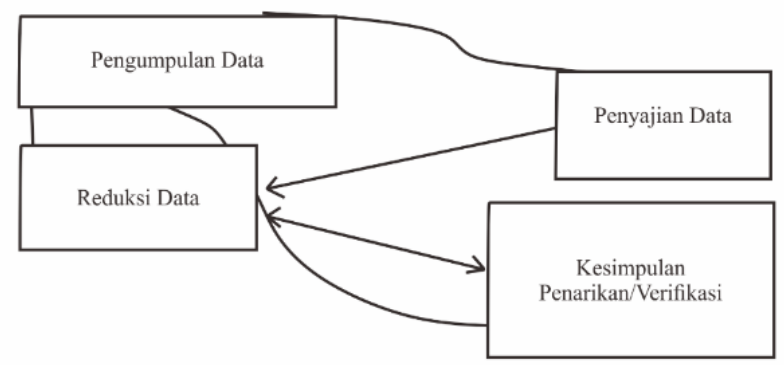

Gambar 1. Komponen - komponen analisis data (sumber: Miles dan Huberman dalam Sugiyono (2017))
Tabel 1. Profil subjek penelitian

\begin{tabular}{lllll}
\hline Kategori & Subjek 1 & Subjek 2 & Subjek 3 & Subjek 4 \\
\hline Nama & Asijah & Nurhilda & Sumie & Triyono \\
& & yanti & Hudiyono & \\
Jabatan & Marketing & Desainer & Pengawas & Pemilik \\
& CV & CV & Produksi- & Elvie \\
& Estetika & Estetika & Jagal & Keramik \\
& Indonesia & Indonesia & Kayu & \\
Sexe & P & P & L & L \\
Pendidikan & S1 & S1 & S1 & STM \\
\hline
\end{tabular}

Analisis komparatif merupakan analisis dengan membandingkan dua atau lebih variable. Tujuan membandingkan produk-produk senirupa dan desain adalah mengungkap persamaan dan perbedaan dari produk-produk tersebut. Pendekatan komparatif sangat fleksibel digunakan karena karya yang dibandingkan dapat mencakup berbagai hal, seperti gaya seni rupa dan desain, sistem penataan interior, figur-figur wanita yang digunakan dalam iklan produk yang berbeda, pemilihan objek-objek fotografi dan lain-lain (Sumartono, 2017). Subjek dalam penelitian ini merupakan pengrajin, marketing, dan desainer di CV Estetika Indonesia juga supplier produk peralatan saji kayu serta tanah liat (Tabel 1).

\section{Hasil dan Pembahasan}

CV Estetika Indonesia adalah perusahaan Indonesia yang didirikan oleh Ronald Wannee pada tahun 2002 di Yogyakarta. Perusahaan yang terletak di Jl. Parangtritis km 9 No. 5, Bantul, Yogyakarta tersebut focus memproduksi beragam aksesoris rumah termasuk peralatan penyimpanan, peralatan saji (tableware), top table, dekorasi dinding, patung, aksesori kamar mandi dan banyak lagi. Dalam penelitian ini, objek yang menjadi kajian adalah produk-produk peralatan saji CV Estetika Indonesia yang berupa nampan (tray), talenan (cutting board), mangkuk (bowl), piring (plate), gelas (glass), dan tatakan gelas (coaster). Penelitian ini mengkomparasi proses perancangan produk dan proses produksi di CV Estetika Indonesia dikaji dari aspek-aspek yang mempengaruhinya serta kelebihan dan kelemahan dari masing-masing material. Aspek-aspek tersebut adalah gaya/tema, finishing, warna, ergonomi, fungsi, dan packaging . Hasil komparasi tersebut disajikan dalam Tabel 2.

Gaya desain dari set produk peralatan saji ini menggunakan perpaduan antara gaya Jepang (Japanese Style) dan gaya Scandinavian. Hal tersebut dapat diamati dari bentuk produk yang sederhana dan minimalis namun tampak rapi dan indah. Japanese 
style pada peralatan saji memiliki bentuk yang halus, rapi, datar dan menggunakan warna-warna yang netral. Warna hitam memberikan tampilan yang minimalis dan kuat pada produk. Gaya Jepang sangat nampak pada bentuk mangkuk pada peralatan saji ini. Mangkuk khas Jepang memiliki kaki pada bagian bawahnya. Bentuk yang sederhana pada tiap produknya menggambarkan budaya Jepang yang tradisional dan simpel.
Gaya desain ini juga lebih mengutamakan fungsionalitas dari produk tanpa menghilangkan nilai keindahannya. Hal tersebut akan memaksimalkan fungsi dari masing-masing dari produk. Gaya Scandinavian memiliki karakteristik warna natural, netral dan monokrom. Scandinavian dapat dilihat dari bentuk yang sederhana, tipis dan menggunakan warna-warna yang sederhana. Japanese style dipadukan dengan Scandinavian style yang berciri khas sederhana, bersih dan elegan.

Tabel 2. Rangkuman perbandingan proses perancangan dan produksi

\begin{tabular}{|c|c|c|}
\hline No & Perbandingan & Produk Kayu \\
\hline 1. & Tahap Desain & $\begin{array}{l}\text { Memerlukan pertimbangan lebih pada } \\
\text { ketebalan karena akan berpengaruh pada } \\
\text { ukuran akhir setelah penyusutan dari proses } \\
\text { finishing. Titik lengkung atau sudut-sudut } \\
\text { produk serta keterangan atau visual hasil akhir } \\
\text { yang ingin dicapai. }\end{array}$ \\
\hline 2. & Bahan Baku & $\begin{array}{l}\text { a. Memerlukan penjemuran kayu yang relatif } \\
\text { lama dari mulai kayu gelondongan hinga } \\
\text { siap bentuk. } \\
\text { b. Bahan baku tidak memerlukan pengolahan } \\
\text { (siap bentuk setelah penjemuran cukup) dan } \\
\text { dipotong sesuai ukuran menggunakan mesin } \\
\text { gergaji. }\end{array}$ \\
\hline & & $\begin{array}{l}\text { c. untuk produk seperti mangkuk dan } \\
\text { semacamnya yang berbentuk dasar silindris } \\
\text { dengan kadar air tinggi akan lebih mudah } \\
\text { dibentuk dan tidak mudah pecah. }\end{array}$ \\
\hline
\end{tabular}

3. Alat

4. Pengukuran

5. Pembentukan

Mesin bubut manual (Bubut Luar dan Dalam) dan Mesin Computer Numerical Control (CNC)

Menggunakan alat ukur mistar.

Produk Masal dengan tingkat akurat yang tinggi di proses menggunaan mesin CNC

Dengan Mesin CNC dapat diproduksi dalam kuantitas yang lebih banyak dan waktu yang terukur.

Setelah dibentuk produk dapat langsung memasuki proses pengamplasan. (Amplas Kasar dan Amplas halus)

6. Tahap Finishing
Aksesoris Dekoratif dan untuk Alat Hidang

Makanan

Natural, Carving, Bakar

Foodgrade (Waterbased dan Beeswax), Dekoratif (Plitur atau Melamin)

Natural: Tanpa finishing tambahan langsung dengan waterbase varnishing

Carving: Dipahat untuk mendapatkan motif lalu finishing varnish.

Bakar: Permukaan dibakar dengan hot spray gun. Warna lebih awet.

\section{Produk Tanah Liat}

Memerlukan pertimbangan lebih pada ketebalan karena akan berpengaruh pada ukuran akhir setelah penyusutan dan resiko pecah saat proses pembakaran. Keterangan dan visual hasil akhir yang ingin dicapai harus jelas, ukuran permukaan harus sesuai dengan ketebalan produk. semakin lebar produk datar maka resiko pecah semakin besar.

a. Bahan baku berwujud mentah: Pasir halus, Tanah merah, kuning dan hitam

b. Bahan mentah harus diolah dengan perbandingan masing-masing bahan mentah yang sesuai untuk menjadi bahan siap bentuk. (Manual: diinjak-injak, Marsinal: percampuran semua bahan hingg didapatkan adonan tanah liat yang elastis dan ulet)

c. Tidak ada kriteria khusus untuk produk yang berbeda. Kualitas olahan bahan baku sama kadarnya untuk dapat dibentuk berbagai macam produk.

Alat putar manual (Putaran Tegak dan Miring) dan Mal Cetakan

Menggunakan patokan satu produk yang telah jadi (sample produk)

Produk dengan Tingkat keakuratan yang tinggi dibentuk dengan Mal Cetakan yang terbuat dari Gipsum.

Dengan Mal Cetakan dapat diproduksi secara masal namun tetap terbatas kemampuan manusia.

Setelah dibentuk produk harus di jemur atau dianginanginkan kemudian masuk ke proses pembakaran. (Api kecil: 6-9 jam dan Api besar: 2-3 jam)

Tidak ada perbedaan finishing untuk produk Dekoratif dan alat hidang. Jenis finishing sama.

Natural, Pengasapan, Teknik Raku

Natural: Tanpa finishing tambahan. Warna yang dihasilkan merah bata.

Pengasapan: Pengasapan menggunakan asap daun munggur, kelapa atau pisang. Berlangsung 2-3 jam.

Warna Coklat kemerahan hanya pada permukaan, warna menggelap tergantung lama pengasapan.

Teknik Raku: Alami dengan Serbuk gergaji kayu. Warna hitam tahan lama karna meresap ke pori-pori. Terdapat efek asap silver pada permukaan. Berlangsung 2-3 jam 


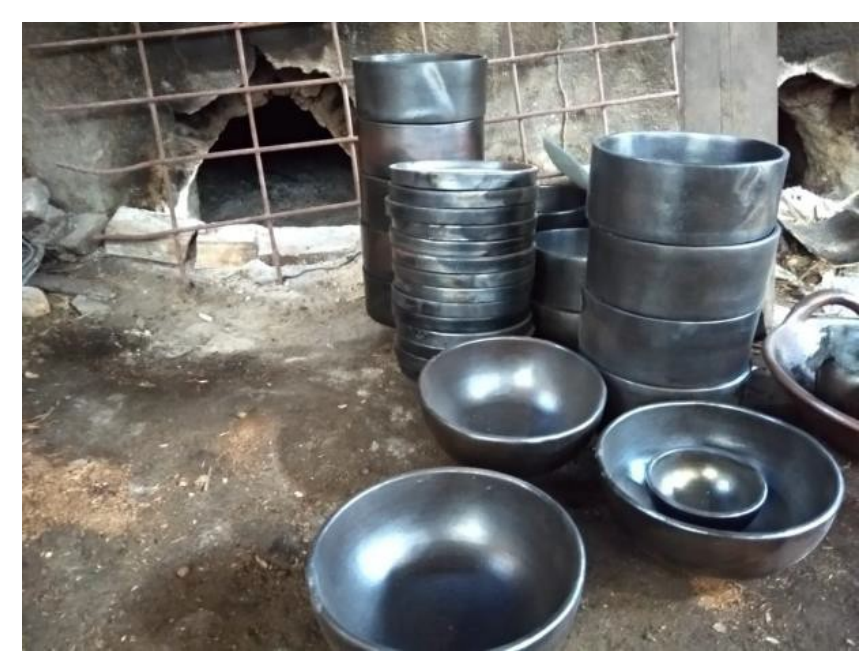

Gambar 1. Hasil Teknik Raku (sumber: dokumentasi penulis)

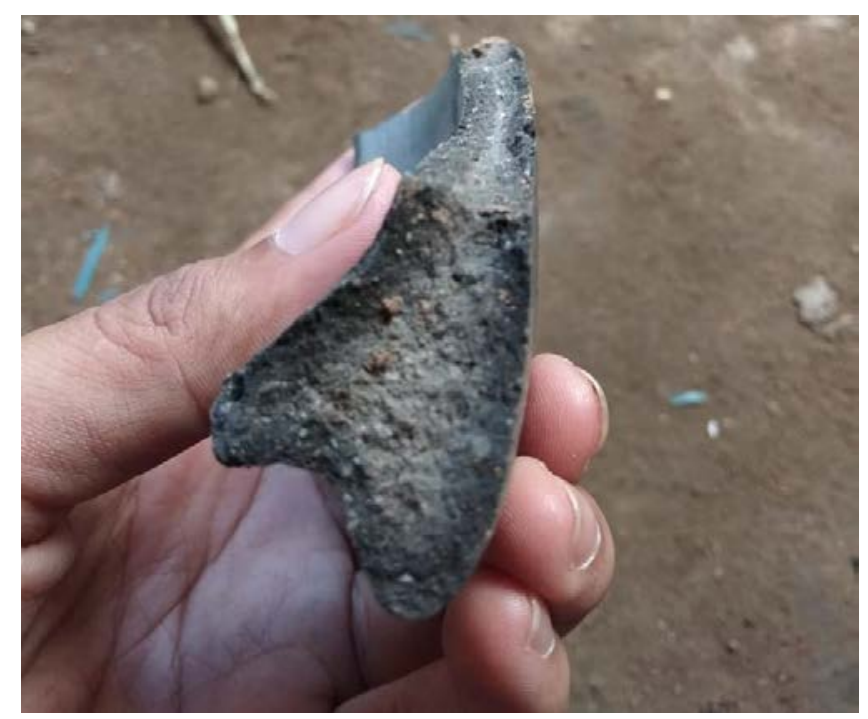

Gambar 1. Peresapan Teknik Raku (sumber: dokumentasi penulis)

Tema yang diangkat pada produk-produk ini adalah "black to black". Warna hitam menjadi trend pada dua tahun terakhir ini. Tema ini juga sesuai dengan tren desain yang berkembang pada tahun 2019 yang didapat dari perusahaan buyer. Warna hitam juga dipakai sebagai konsep beberapa pameran desain seperti Ambiente 2018-2019 yang diselenggarakan di Jerman.

Sama halnya dengan produk peralatan saji dari material tanah liat, peralatan saji dari material kayu juga diidentifikasi gaya dan tema yang diangkat dalam perancangan produk di atas. Tidak jauh berbeda, gaya yang diangkat masih bersangkutan dengan moderen Scandinavian dengan tema natural. Gaya netral. Dalam penerapan gaya ini, bentuk produk lebih dinamis dan tidak destruktif. Bentuk lebih flat dengan lengkung yang simetris untuk mendapatkan kesan simplicity dan moderen. Material yang digunakan juga diekspos natural. Material kayu yang dipilih adalah kayu munggur atau yang sering disebut kayu suar. Kayu ini memiliki serat kayu yang indah dan ketahanan yang cukup kuat. Tema natural Scandinavian ini masih mengacu pada tren desain yang berkembang.

Aspek finishing juga menjadi objek kajian dalam penelitian ini. Finishing merupakan proses akhir dari proses perancangan produk. Proses finishing ini dilakukan untuk menyempurnakan dan mempercantik produk. Pada peralatan saji dengan material tanah liat ini finishing dilakukan dengan teknik Raku, yakni teknik dimana produk dalam kondisi sangat panas langsung ditimbun dengan serbuk gergaji kayu. Proses ini akan memberikan efek warna hitam dengan biasan silver pada produk (Gambar 1). Warna hitam akan meresap sekitar 0,5 centimeter ke dalam produk (Gambar 2). Permukaan produk menjadi matte dan elegan. Finishing matte ini juga menjadi trend season pada tahun 2018-2019 ini.

Seperti yang telah dibahas di atas, bahwa desain Scandinavian memiliki karakteristik simple dan alami. Finishing yang diaplikasikan pada produk ini menggunakan bahan-bahan alami tanpa ada kimia. Seperti yang kita tahu bahwa produk-produk ini akan difungsikan sebagai peralatan saji yang akan berkenaan langsung dengan makanan sehingga harus aman bagi kesehatan manusia (foodgrade).

Aplikasi finishing pada peralatan saji dari kayu diatas adalah natural, burning dan blackwash. Produk kayu yang telah melalui proses penghalusan (amplas) akan diberikan finishing akhir menggunakan cairan biopolish waterbase atau beeswax. Cairan biopolish waterbase dan beeswax merupakan bahan finishing kayu yang terbukti aman bagi kesehatan manusia dan mendapat label foodgrade. Finishing bipolish waterbase ini memiliki berbagai warna pada hasil akhirnya, namun yang diterapkan pada produk ini adalah natural dan black wash pada cutting board di atas. Bahan finishing beeswax terbuat dari sari lebah. Perbedaan kedua bahan ini terletak pada kilap yang dihasilkan dan ketahanan dari finishing tersebut. Biopolish waterbase dapat lebih bertahan lama dibandingkan dengan bahan beeswax. Produk di atas juga menerapkan finishing bakar pada permukaannya. Finishing ini dilakukan dengan membakar permukaan produk yang dikehendaki menggunakan spray gun sampai warna yang diinginkan. Kemudian finishing ini akan dibersihkan dari abu yang menempel pada 
permukaan yang setelah nampak serat yang diinginkan akan diberikan finishing akhir waterbase maupun beeswax. Efek mengkilat dari finishing waterbase akan lebih nampak dibandingkan dengan beeswax.

Selain gaya dan finishing, aspek penting lainnya adalah warna. Warna dalam desain Japanese dan Scandinavian memiliki kemiripan yaitu netral dan natural. Pada produk ini warna yang diambil sesuai dengan tema "black to black" yaitu hitam. Teknik finishing raku memberikan warna hitam kelam dengan efek silver pada permukaan produk. Warna hitam dalam produk peralatan saji memberikan kesan pada hidangan menjadi lebih lezat dan nikmat. Warna hitam ini akan memberikan fokus utama pada hidangan yang disajikan. Pada produk peralatan saji berbahan kayu, warna natural dari kayu ditonjolkan dengan aksen warna hitam hasil dari finishing bakar memberikan tampilan yang elegan (Gambar 3). Warna hitam tetap menjadi point of interest dari produk pada season ini. Warna natural kayu memberikan kesan kekeluargaan, nikmat dan tenang sehingga suasana meja makan menjadi hangat.

Ergonomi merupakan aspek penting yang perlu pula dikaji. Ergonomi merupakan aspek yang berkaitan dengan nilai keamanan, keselamatan dan kenyamanan produk untuk manusia. Pada produk peralatan saji tentu saja aspek ini penting untuk pertimbangan keamanan produk dari berbagai zat kimia berbahaya, bentuk produk, dan pengaruh suhu
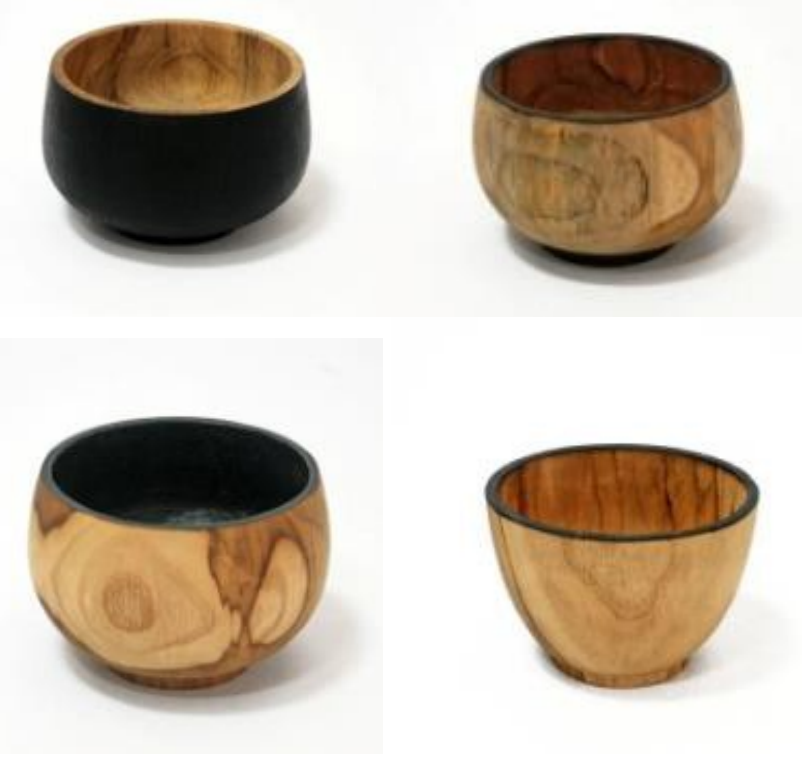

Gambar 3. Mangkuk kayu CV Estetika Indonesia (sumber: dokumentasi penulis) makanan pada material produk. Pengaruh bentuk dari produk saat dipergunakan oleh manusia, akankah melukai tangan atau tidak sehingga nyaman saat dipergunakan. Pada produk peralatan saji ini, material dan finishing yang digunakan sangat alami dan aman bagi kesehatan manusia sehingga dapat memenuhi keamanan dari sudut pandang ini. Produk-produk set ini menggunakan bentuk datar dan lengkung sehingga tidak akan melukai pengguna. Pada produk alat saji, bentuk-bentuk runcing sebaiknya dihindari. Ukuran dari produk tentu saja disesuaikan dengan standar ukuran masing-masing produk yang telah disesuaikan dengan fungsi produk masing-masing.

Produk-produk ini juga telah lolos dari tes keamanan dan keselamatan untuk diekspor ke luar negeri sehingga ergonomi dari produk peralatan saji tanah liat ini dapat terpenuhi. Tak jauh berbeda dengan peralatan saji material tanah liat, aspek ergonomi dari produk peralatan saji kayu ini juga dapat memenuhi standar keamanan, keselamatan dan kenyamanan dari produk. Hal tersebut dapat diidentifikasi dari material yang digunakan adalah kayu. Material ini sudah tidak diragukan lagi keamanannya. Finishing yang diaplikasikan juga alami dan foodgrade, sehingga tidak mengandung bahan yang berbahaya. Bentuk dari produk-produk ini juga hampir sama dengan alat saji tanah liat, bentuk lengkung dan datar mendominasi. Hal tersebut berkaitan dengan keamanan dan keselamatan pengguna karena produk ini bersentuhan langsung dengan kegiatan pengguna.

Dalam bidang desain, terutama desain produk, aspek fungsi merupakan hal penting yang menjadi pertimbangan dalam perancangan. Fungsional dari produk dapat diidentifikasi dari material yang digunakan dan bentuk dari produk. Dalam kasus ini, set peralatan saji yang terdiri dari beberapa produk tentu saja memiliki fungsi yang berbeda. Mangkuk, piring, gelas, coaster, dan lain sebagainya diproduksi dengan material tanah liat ini dinilai aman dan sesuai dengan fungsinya. Kepadatan material dan hasil akhir dari proses produksi memiliki ketahanan terhadap air yang sesuai sehingga produk dapat difungsikan untuk menghidangkan aneka sayur, kuah, lauk dan sebagainya. Bentuk dari produk yang simple dan tidak meliuk-liuk membuat fungsional dari produk dapat tercapai dengan maksimal. Material tanah liat ini juga lebih tahan panas dibandingkan dengan material kayu. Alat saji dari material ini dinilai lebih fungsional dibandingkan dengan produk alat saji dari kayu. Meskipun berat, tingkat ketahanannya terhadap air dan panas membuat produk ini lebih awet dan diminati banyak pengguna. Sedangkan produk dari 
kayu yang lebih ringan akan memudahkan pengguna dalam penyajian hingga menghidangkan sajian di meja penghidangan. Fungsional produk dari material kayu untuk makanan dinilai kurang dibandingkan dengan material tanah liat, hal tersebut dikarenakan finishing dari produk kayu menggunakan bahan pelapis sehingga saat pelapis mulai memudar kayu tidak dapat langsung mengenai makanan basah khususnya sajian berkuah panas. Finishing pada produk kayu juga memerlukan perhatian khusus dalam penyajian makanan berkuah tidak dianjurkan untuk langsung menuangkannya pada mangkuk kayu dalam kondisi panas karena pelapis kayu dapat larut. Produk alat saji dari kayu lebih banyak dipergunakan untuk makanan kering.

Aspek terakhir yang dikaji adalah packaging atau pengemasan. Pengemasan produk dari material tanah liat memerlukan beberapa lapisan yakni sterofoam, foam wrap, dan kardus. Styrofoam difungsikan untuk menahan produk tanah liat didalam kardus agar tidak terbentur karena longgar sehingga dapat menyebabkan keretakan hingga pecah.pada sterofoam juga diberikan kedalaman khusus sesuai dengan permukaan produk untuk menahan produk dari pergeseran saat pengiriman. Foam wrap digunakan untuk melapisi atau membungkus produk agar lebih aman karena tidak adanya gesekan antara produk langsung dengan sterofoam atau kardus. Lapisan terluar adalah kardus. Kardus berfungsi untuk penataan barang yang sesuai dan rapi sehingga produk tetap terjaga posisinya saat pengiriman. Pengemasan produk tanah liat lebih memerlukan kehati-hatian. Hal tersebut karena karakteristik produk tanah liat yang mudah pecah, sehingga packaging harus lebih optimal untuk meminimalisir pecahnya barang saat pengiriman. Proses packaging tanah liat tentu saja akan menambah biaya dan resiko juga rentan. Dibandingkan pengemasan produk kayu, produk tanah liat lebih kompleks.

Packaging produk kayu hanya memerlukan foam wrap dan kardus saja. Sifat produk kayu yang kuat, ringan dan tidak rentan pecah memudahkan proses packaging dan pengiriman. Pada kardus juga telah diberikan simbol-simbol keterangan yang menggambarkan sifat isi kemasan. Walaupun produk dari kayu lebih kuat dan tidak rentan pecah, simbol fragile tetap diberikan untuk mengantisipasi hal-hal yang tidak diinginkan saat pengiriman. Simbol keep in dry diberikan supaya produk tetap dijaga kekeringannya dan dijauhkan dari cairan. Handle with care digunakan untuk memberi keterangan pada petugas pengiriman agar berhati-hati saat memindahkan barang. Untuk packaging dari tanah liat ditambahkan simbol Top untuk memberi keterangan bahwa produk tidak boleh terbalik dalam peletakannya saat pengiriman.

\section{Kesimpulan}

Proses perancangan produk peralatan saji berbasis material kayu dan tanah liat di CV Estetika Indonesia mengacu pada brief yang diberikan oleh buyer. Brief yang berisi mengenai konsep produk akan diterjemahkan oleh desainer kemudian dilanjutkan proses brainstorming dan studi literatur melalui media daring. Proses desain dilakukan menggunakan software 2D maupun 3D. Proses perancangan dan proses produksi peralatan saji berbahan dasar kayu dilakukan dengan mesin sehingga lebih presisi dan sesuai dengan konsep mass product atau produk industry. Sedangkan peralatan saji dengan material tanah liat lebih mengarah pada handycraft karena produk diproduksi secara manual menggunakan tangan.

Produk peralatan saji CV Estetika Indonesia terdiri dari produk dengan material kayu dan tanah liat. Produk dengan material kayu diproduksi di daerah Putat Wetan, Patuk, Gunungkidul, DI Yogyakarta. Produk peralatan saji dengan material kayu terdiri dari mangkuk (bowl), piring (plate), gelas, nampan (tray) dan talenan (serving board/cutting board). Sedangkan untuk material tanah liat, produk yang dihasilkan tidak jauh berbeda dengan produk-produk perusahaan lainnya yaitu, mangkuk (bowl), piring (plate), nampan (tray), gelas (glass), dan tatakan gelas (coaster).

Produk peralatan saji yang terbuat dari material dasar kayu dan tanah liat di CV Estetika Indonesia kebanyakan dirancang khusus mengacu pada tren desain yang sedang berlangsung (ScandinavianNatural). Tema yang dipilih sesuai brief yang diinginkan oleh pasar yang saat penelitian dilakukan didominasi oleh warna monokrom dan finishing natural. Finishing yang dipilih cenderung natural dengan menggunakan bahan-bahan yang termasuk dalam kategori foodgrade. Warna yang dipilih sesuai dengan tren dan gaya desain yang diaplikasikan yakni "black to black". Sedangkan produk peralatan saji dari tanah liat dinilai lebih ergonomis daripada material kayu karena bahan yang digunakan lebih tahan terhadap makanan basah maupun kering. Sekalipun demikian, peralatan dari material kayu memiliki bobot yang lebih ringan sehingga memudahkan pengguna saat memindahkan dan menyajikan di meja penyajian. 


\section{Daftar pustaka}

Andreani, A. P., \& Prasetya, R. D. (2019). Petrified Wood: Karakteristik dan Aplikasinya dalam Bidang Desain Produk. Jurnal Rekarupa, 5(2).

Gitosudarmo, I. (2000). Manajemen Pemasaran (1st ed.). Yogyakarta: BPFE.

Insani, H. M., Nikmawati, E. E., \& Mahmudatussa'adah, A. (2016). Analisis pengetahuan peralatan boga mahasiswa prodi pendidikan tata boga dalam ujian seni tata hidang. Media Pendidikan, Gizi Dan Kuliner, 5(1), 8-17.

Jayadi, N., \& Prasetya, R. D. (2017). Pengembangan desain produk berbahan baku limbah kerang di Bantul. PRODUCTUM Jurnal Desain Produk (Pengetahuan Dan $\begin{array}{llll}\text { Perancangan } & \text { Produk), }\end{array}$ https://doi.org/10.24821/productum.v3i1.1736

Oentoro, K. (2019). Pengembangan desain teko set gerabah kontemporer berbasis budaya lokal di Kabupaten Bojonegoro.
Productum: Jurnal Desain Produk (Pengetahuan Dan Perancangan Produk), 3(6), 189-196. https://doi.org/https://doi.org/10.24821/productum.v3i6.2431

Prasetya, R. D. (2015). Potensi Limbah Kayu Industri Mebel untuk Produk Home Accessories. PRODUCTUM Jurnal Desain Produk (Pengetahuan Dan Perancangan Produk). https://doi.org/https://doi.org/10.24821/productum.v1i1.1652

Sugiyono. (2017). Metode Penelitian Kuantitatif, Kualitatif, dan $R \& D$. Bandung: Alfabeta.

Sulartiningrum, E. S. (2001). Pengantar Akomodasi dan Restoran. Jakarta: PT Gramedia Pustaka Utama.

Suranny, L. E. (2015). Peralatan Dapur Tradisional Sebagai Warisan Kekayaan Budaya Bangsa. Jurnal Arkeologi Papua, 7(1), 47-62.

Yustana, P. (2014). Bayat Ceramic (Aesthetic, Form, And Function). Acintya Jurnal Penelitian Seni Budaya, 6(1), 1432. https://doi.org/https://doi.org/10.33153/acy.v6i1.179 